\title{
THE EFFECT OF OWNERSHIP STRUCTURE, PROFITABILITY, FIRM SIZE AND TANGIBILITY ON CAPITAL STRUCTURE
}

\author{
Tika Iswarini ${ }^{\bowtie}$, Anindya Ardiansari \\ Management Department, Faculty of Economics, Universitas Negeri Semarang, Semarang, Indonesia
}

\section{Info Article}

History Article:

Received September 2018

Approved December 2018

Published December 2018

Keywords:

Capital Structure; Manaje-

rial Ownership; Institutional

Ownership; Profitability; Firm

Size; Tangibility.

\begin{abstract}
The important decision faced by financial management which relates to the continuity of company operations is funding decision which is capital structure. Capital structure achieves optimal value if the composition of debt and capital are able to increase company value. The purpose of this research is to examine the effect of ownership structure, profitability, firm size, and tangibility against capital structure (research on manufacturing companies listed on Indonesia Stock Exchange period 2012-2016). The population in this research were all manufacturing companies listed on the Indonesia Stock Exchange 2012-2016. This research used a purposive sampling method with certain criteria to determine the sample. The sample used was 38 companies with the research period 2012-2016 at manufacturing companies listed on the Indonesia Stock Exchange. Multiple regression analysis using Eviews 8 was used to analyze the data. The result of multiple linear regression test showed that there were three independent variables that affect capital structure they were managerial ownership, firm size and tangibility. Whereas institutional ownership and profitability did not affect the capital structure of manufacturing companies in 2012-2016. The conclusion of this research is managerial ownership, firm size and tangibility have a positive and significant effect on capital structure, while institutional ownership and profitability have negative and insignificant effect on capital structure.
\end{abstract}

\begin{abstract}
Abstrak
Keputusan penting yang dihadapi oleh manajemen keuangan yang berkaitan dengan kelangsungan operasi perusahaan adalah keputusan pendanaan yang merupakan struktur modal. Struktur modal mencapai nilai optimal jika komposisi hutang dan modal mampu meningkatkan nilai perusahaan. Tujuan dari penelitian ini adalah untuk menguji pengaruh struktur kepemilikan, profitabilitas, ukuran perusahaan, dan tangibilitas terhadap struktur modal (penelitian pada perusahaan manufaktur yang terdaftar di Bursa Efek Indonesia periode 2012-2016). Populasi dalam penelitian ini adalah semua perusahaan manufaktur yang terdaftar di Bursa Efek Indonesia 2012-2016. Penelitian ini menggunakan metode purposive sampling dengan kriteria tertentu untuk menentukan sampel. Sampel yang digunakan adalah 38 perusahaan dengan periode penelitian 2012-2016 di perusahaan manufaktur yang terdaftar di Bursa Efek Indonesia. Analisis regresi berganda menggunakan Eviews 8 digunakan untuk menganalisis data. Hasil uji regresi linier berganda menunjukkan bahwa terdapat tiga variabel independen yang mempengaruhi struktur modal yaitu kepemilikan manajerial, ukuran perusahaan, dan tangibilitas. Sedangkan kepemilikan institusional dan profitabilitas tidak mempengaruhi struktur modal perusahaan manufaktur pada 2012-2016. Kesimpulan dari penelitian ini adalah kepemilikan manajerial, ukuran perusahaan dan tangibilitas berpengaruh positif dan signifikan terhadap struktur modal, sedangkan kepemilikan institusional dan profitabilitas berpengaruh negatif dan tidak signifikan terhadap struktur modal.
\end{abstract}




\section{INTRODUCTION}

In facing competition, every company has to grow and develop sustainably in order to make stakeholders believe the company. To support business' growth and development, the company needs funding or capital source to be able to fund its operational and investment activities (Komara et al., 2016). Problems of funding management relate to how the company determines funding source that will be used to run and develop investment and operational activities of the company (Nisak \& Ardiansari, 2016).

One of the important decisions faced by financial managers which related to the continuity of the company's operations is capital structure decision that is a financial decision related to debt composition, share preferred and common share (Indriani \& Widyarti, 2013). According to Nugroho (2014) capital structure is a balance or comparison between external capital and own capital. In this case, external capital is debt, both in long term and short term. Whereas the capital itself can be divided into retained earnings and company ownership. According to Haryanto (2013), capital structure will affect the market value of the company by minimizing capital cost average. Optimal capital structure is a capital structure which can minimize capital cost average and maximize company value.

According to Sheisarvian et al. (2015) making debt, the policy is not easy because there are many parties in the company which has different interests so that decision makers will not be separated from agency conflicts which occur in the company. This relationship is called agency relationship. Interests combination of each party often creates a problem called agency conflict. Jensen and Meckling (1976) said that agency relationship is the relationship between principal and agent. Both parties should have alignment in looking for profits. But agents do not always take profitable decisions for the principals.

According to Pratiwi and Yulianto (2016) the existence of ownership separation and company control creates agency relationships. Share ownership managerial may cause managerial behavior to gain personal profit and take over shareholder wealth and ignore interests' equality between managers and shareholders. According to Salehi et al. (2017) ownership structure of the company listed generally consists of two aspects: the degree of ownership concentration and identity or nature of controlling shareholder. Controlling shareholder includes institutional ownership, managerial ownership, family ownership and go- vernment ownership. The degree of ownership concentration refers to the percentage of voting rights owned by the largest shareholders. Anita and Yulianto (2016) said that managerial ownership is able to affect the company's operation which ultimately affects the company's performance in achieving the goals of the company.

If managerial ownership structure increases, the amount of personal wealth and capital invested in the company also increases, so the managers tend to use low debt to reduce all risk and agency costs. Debt is used not only to align shareholders and managers interest, but it also has a risk on corporate bankruptcy so that managers are at risk of losing their jobs. These provide motivation for managers to reduce wasteful consumption for the sake of their personal interest and improve the efficiency of their work (Moh'd et al., 1998).

According to Hasan and Butt (2009), managerial ownership has negative effect against the capital structure, the big amount of debt increases bankruptcy risk so that high managerial ownership causes the managers to reduce the level of debt. The study is in line with Sumani (2012) which found a significant negative effect on the relationship between managerial ownership against the capital structure. It means that high managerial ownership will reduce the amount of debt used by the company.

In contrast to the research by Shoaib and Yasushi (2015) and Yulianto (2013) says that managerial ownership has a significant positive effect on capital structure. The enhancement of managerial ownership will increase the use of debt. It is because the manager's share ownership will encourage managers to behave entrenchment, so shareholders will use debt as a creditor monitoring mechanism for managerial performance which they have an effect on the increased of agency costs. Whereas Laksana and Widyawati (2016) said that there is no influence between managerial ownership against the capital structure. The existence of institutional ownership in the company helps to improve long-term finance at a favorable cost. In addition, institutional ownership also has a function to monitor the effective strategic decisions for the company. Institutional ownership causes lower agency costs and reduces managerial opportunism (Hasan \& Butt, 2009).

According to Laksana and Widyawati (2016) and Maftukhah (2013) stated that institutional ownership has a positive influence on capital structure. Institutional ownership has greater authority when it is compared to other stakeholders group to choose risky projects by hoping 
that the company will earn high profits. To fund the project, investors tend to choose to finance through debt which will improve their capital structure.

It means that higher institutional ownership in the company will cause higher debt. In contrast to Chung and Wang (2014) and Rossi Cebula (2016) says that there is significant negative effect between institutional ownership on capital structure. Institutional ownership can replace the role of debt discipline in monitoring manager behavior. The amount of institutional ownership affects the manager's conservative behavior in debt issuance. In this case, high institutional ownership decreases the amount of debt. Meanwhile, according to Susilawati et al. (2012) institutional ownership has an insignificant negative effect on capital structure.

The company uses funds which are generated internally as a top priority then the second option is debt and the last option is share, it is in accordance with pecking order theory (Hasan \& Butt, 2009). At a low profitability level, the company uses debt to finance the company. In turn high profitability level, the company reduces the use of debt. This is because the company allocates most of the profits on retained earnings so that it relies on internal sources and uses low debt (Maftukhah, 2013).

Pecking order theory also says that the reason for companies which prefer to choose internal funding is to prevent companies from asymmetric information problems (Pujiharjanto et al., 2014). The greater the profits, the company will use lesser debt. This is in line with the prediction of pecking order theory model that prioritizes internal funding through retained earnings and then if internal funding conditions are limited, the use of external funding will be quite large (Yulianto et al., 2015). According to Febriana and Yulianto (2012) shares will never be issued because of having the highest asymmetry problems information. According to Myers and Majluf (1984), First funding used by the company is internal funding because it is considered to have a low cost. The second is external funding that is debt and the last is issuing share.

Indriani and Widyarti (2013) say that profitability has a negative effect on the capital structure, the sign that is resulted from this study shows that any decline in profitability will increase capital structure, vice versa. In line with Matias and Serrasqueiro (2016) who also said that profitability has a negative effect on capital structure. In contrast to the research by Nugroho (2014) which says that there is positive effect bet- ween profitability and capital structure, it means that any increase in profitability will be followed by the increase of capital structure. This discovery is in accordance with the trade-off theory which states if the debt of the company is higher it will increase the company's value in terms of profitability. While the study by Nisak and Ardiansari (2016) said that there is no effect of profitability on capital structure.

A company will get more benefit from its operations (Khafid \& Nurlaili, 2017). But the larger the size of the company, the greater the need for funds, which one of them can come from external funding, that is debt. Large companies have advantages and activities which are known by the public rather than small companies, so huge need of debt of the company will be higher than small companies. In addition, the larger the company size, the more transparent in expressing company's performance to the outsiders, so the company will be easier to get a loan because the company is more trusted by corporate creditors (Sudiyatno \& Sari, 2013). Firm size is the size or the size of assets owned by the company. Companies that are in high sales growth require greater corporate resource support. Likewise, on the contrary, in companies with low sales growth rate, the need for corporate resources is also getting smaller (Zuhria \& Riharjo, 2016).

Nugroho (2014) says there is a negative effect of firm size on capital structure. Companies with high assets are able to maximize their assets by placing their own cash as the main operational source so it can reduce their debt. It means that the larger the company size the capital structure will be lower. Unlike Zuhria and Riharjo (2016) say that company size has a positive effect on capital structure.

The larger the firm size then the tendency to use capital is also greater, this is because large companies need large funds also to support their operations. The size of company size will affect the capital structure, the greater the company, the greater the funds required for the company to invest. Zuhria and Riharjo (2016) are in line with research conducted by Oino and Ukaegbu (2015).

Companies which have sufficient asset to be used as loan collateral tend to use pretty much debt. Common assets which can be used by many companies can be a good guarantee. Assets owned by the company will affect the relationship between the company and other parties. Assets are one of the guarantees which can convince others parties to give a loan to the company, so the companies with more flexible structures will find an easier loan. Companies whose ass- 
ets are in accordance with credit guarantees will use more debt because the creditors will always provide a loan if it has a guarantee (Brigham \& Houston, 2013).

Large assets will show the company's ability to provide higher assurance, so by assuming that all other factors are constant, the company will increase its debt to get profits from the use of debt (Agustini \& Budiyanto, 2015). According to Laksana and Widyawati (2016) with high levels of tangibility, if the company is experiencing financial difficulties or even bankruptcy, the creditor is entitled to tangible assets of the company which have been guaranteed. Companies with a large proportion of their assets composed of tangible assets will tend to have high debt levels. Conversely, the lower the tangibility of the company, the lower the ability of the company to be able to guarantee its debt in the long-term.

Hardiningsih and Oktaviani (2012) say that there is a positive and significant effect of tangibility (asset structure) on the capital structure. The ownership of large fixed assets and the offer of easy loans and the opportunity to invest will be a consideration for companies to decide to take the debt, companies that have large fixed assets have the potential to have large debts as well. The study is in line with research by Agustini and Budiyanto (2015) say that the tangibility (asset structure) also has a positive effect on capital structure. But it is not in line with research by Yuhasril (2006) says that there is a significant negative effect of tangibility (assets structure) on the capital structure.

The following are empirical data on Debt To Equity (DER), managerial ownership, institutional ownership, profitability, firm size and tangibility in manufacturing companies can be seen in Table 1.

Based on the Table 1, it can be seen that the average of Debt Equity Ratio (DER), managerial ownership, institutional ownership, profitability, firm size and tangibility in manufacturing companies show fluctuating conditions. Managerial ownership in 2016 is $0.113 \%$ and 2015 is $0.116 \%$, managerial ownership in 2016 decreased, followed by Debt Equity Ratio which decreased in 2016 from $1.49 \%$ to $1.25 \%$. So it means that low share ownership causes decreasing of debt. This is not in accordance with Agency Theory which says that the higher the share ownership the capital structure will decrease.

Institutional ownership from 2013 to 2015 always increased by $0.69 \%, 0.74 \%$ and $0.76 \%$, followed by Debt Equity Ratio which also increased from 2013 until 2015 which is $1.30 \% ; 1.33 \%$; and $1.49 \%$. Then it means that high institutional ownership will lead to an increase in debt. This is not in accordance with Agency Theory which says that the higher the institutional ownership the capital structure will decrease.

In 2016, profitability decreased from $3.66 \%$ to $2.61 \%$, followed by a decrease of Debt Equity Ratio in 2016 also decreased from 1.49\% to $1.25 \%$. Then it means that lower profitability causes lower levels of debt. This is different from the Pecking Order theory which states that the higher the profitability then the level of capital structure will be lower.

Firm size increased in 2016 from 12.82\% to $12.83 \%$, while Debt Equity Ratio in 2016 decreased from $1.49 \%$ to $1.25 \%$ means that the higher company size the debt will be lower. This is in contrast to the theory which says that the higher the firm size causes the increased debt levels.

Assets structure (tangibility) increased in 2016 from $1.18 \%$ to $1.19 \%$, while Debt Equity Ratio in 2016 decreased from $1.49 \%$ to $1.25 \%$ means that the higher the structure of tangibility of the company, the debt will be lower. This is in contrast to the theory that the higher the asset structure (tangibility) causes increased debt levels.

Table 1. Average Percentage of DER, Managerial Ownership, Institutional Ownership, Profitability, Firm Size and Tangibility in Manufacturing Companies in the period 2012-2016

\begin{tabular}{lrrrrr}
\hline \multicolumn{1}{c}{ Variable } & $\mathbf{2 0 1 2}$ & $\mathbf{2 0 1 3}$ & $\mathbf{2 0 1 4}$ & $\mathbf{2 0 1 5}$ & \multicolumn{1}{c}{$\mathbf{2 0 1 6}$} \\
\hline DER & 1.120 & 1.300 & 1.330 & 1.490 & 1.250 \\
Managerial Ownership & .119 & .119 & .116 & .116 & .113 \\
Institutional Ownership & .880 & .690 & .740 & .760 & .630 \\
Profability & 6.470 & 4.770 & 3.220 & 3.660 & 2.610 \\
Firm size & 12.610 & 12.790 & 12.820 & 12.820 & 12.830 \\
Tangibility & 1.110 & 1.140 & 1.140 & 1.180 & 1.190 \\
\hline
\end{tabular}




\section{Hypotheses Development}

Managerial ownership is the ownership of shares held by the management of the company. Managerial ownership is a tool that can be used to reduce agency conflict (Laksana \& Widyawati, 2016). Share ownership by managers has a negative effect on capital structure because managers tend to use low debt to reduce all risk and agency costs when their share ownership increases, with the, increased of managerial ownership the amount of personal wealth and capital which is invested in the company also increases (Moh'd et al., 1998). The increased of managerial ownership will motivate the managers to reduce the cost of debt and be more careful in managing corporate finance. High debt costs cause the risk of bankruptcy of the company increase if the company experience bankruptcy then the manager will have a risk to lose his job. So high managerial ownership leads managers to make decisions to use low debt costs. This statement is in accordance with the research by Hasan and Butt (2009) and Sumani (2012) which states that the higher the managerial ownership, the lower the capital structure level.

H1: Managerial ownership has a significant negative effect on capital structure.

Institutional ownership is the ownership of shares by governments, financial institutions, incorporated institutions, overseas institutions, trust funds and other institutions (Laksana \& Widyawati, 2016). A high degree of institutional ownership has a function to monitor the effective strategic decisions for the company, then cause low agency costs and reduced managerial opportunism (Hasan \& Butt, 2009). According to Laksana and Widyawati (2016), control or supervision owned by outside parties can affect decision-making made by the managers which relate to the company's capital structure in terms of investment decisions. High and effective institutional ownership levels in a company can replace the role of debt as a management control tool so it can reduce the use of debt and reduce agency problems. Therefore institutional ownership has a negative effect on capital structure. The statement is in accordance with the research by Chung and Wang (2014) and Rossi and Cebula (2016) says that the higher institutional ownership, the lower the capital structure level will be.

$\mathrm{H} 2$ : Institutional ownership has a significant negative effect on capital structure.

Profitability is one measurement for company's performance which shows the ability of the company to generate profit over a certain period at a certain level of sales, assets and capital share (Laksana \& Widyawati, 2016). According to Myers and Majluf (1984), the company would prefer to use internal funding to finance the investment because internal funding is considered to be cheap, if the company is required to use external fund then the first option used is debt after that issuance of new shares.

Pecking order theory says that companies with high profits will reduce debt cost because there are more internal funds for financial investment. The statement shows that profitability has a negative effect on capital structure, in line with the research by Indriani and Widyarti (2013) and Matias and Serrasqueiro (2016) say that the higher the profitability, the lower the capital structure.

H3: Profitability has a significant negative effect on capital structure.

Firm size is the size or amount of assets owned by the company. Companies that are in high sales growth need big corporate resource support. In turn, companies with low sales growth rate, the need for corporate resources is also smaller. Firm size will affect the capital structure (Zuhria \& Riharjo, 2016). According to Sudiyatno and Sari (2013), large companies can lead to higher debt because the larger the company, funding need is also getting bigger, which can come from the external fund, that is debt. Large companies have special quality and activities which is known by the public compared to small companies, so the needs for the debt of big companies will be higher than smaller companies.

According to Widianti and Andayani (2015), it is in line with the pecking order theory which states that, if the use of internal funds is not sufficient then the second alternative is used that is using debt. This statement is in line with the research by Zuhria and Riharjo (2016) and Oino and Ukaegbu (2015) which states that the larger the firm size the capital structure level will be higher.

H4: Firm size has a significant positive effect on capital structure.

According to Natasia and Wahidahwati (2011) assets are assets owned by the companies which are used for their operations. Generally, there are two types of assets owned by the company they are current assets and fixed assets. Brigham and Houston (2013) said that assets are one of guarantee which can convince others to give a loan to the company so that the companies 
with more flexible asset structure will be easier to obtain loans. Companies whose assets are in accordance with credit guarantees will use more debt because creditors will always give loan when the companies have a guarantee (Brigham \& Houston, 2013).

Assets structure (tangibility) has a positive effect on the capital structure because companies whose assets are sufficient to use as loan collateral tend to use pretty much debt. Common assets which can be used by many companies can be a good guarantee. The statement is in line with research by Hardiningsih and Oktaviani (2012) and Agustini and Budiyanto (2015) say that there is a positive and significant effect of the tangibility (assets structure) on capital structure. Large fixed ownership assets and the offer of easy loans and the opportunity to invest will be a consideration for companies to decide to take debt, companies which have large fixed assets have potential to have large debts as well.

H5: Tangibility has a significant positive effect on capital structure

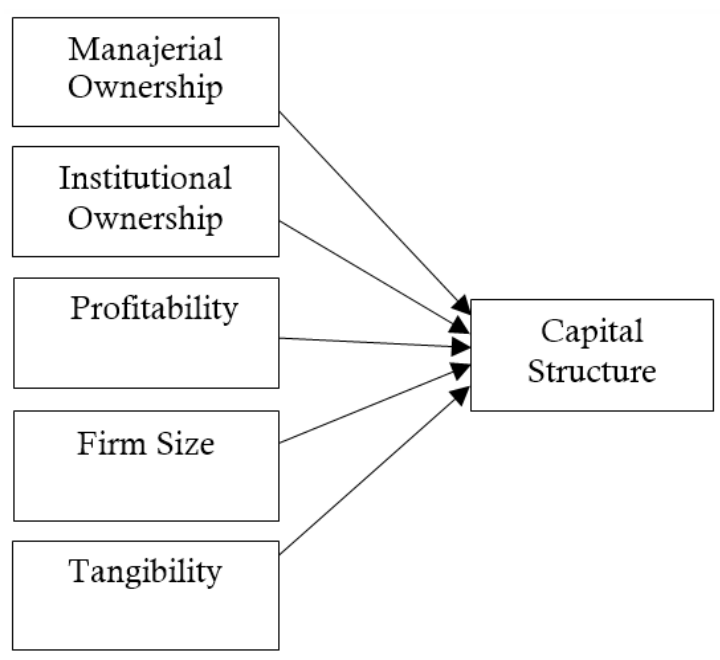

Figure 1. Research Model

\section{METHOD}

This research used a quantitative approach which aims to determine the effect of managerial ownership, institutional ownership, profitability, company size and tangibility against the capital structure. The population in this research is a manufacturing company listed on the Indonesia Stock Exchange in the period 2012-2016. The total population was 132 companies.

The sample used in this research was 190 observation data, by using purposive sampling method with criteria: (1) Manufacturing companies listed on Indonesia Stock Exchange are not delisted from Indonesia Stock Exchange during period 2012-2016. (2) A manufacturing company is issuing financial statements periodically on the Indonesia Stock Exchange in the period 20122016. (3) Manufacturing companies which used the same reporting currency during the research period 2012-2016 that is the rupiah currency. (4) Manufacturing companies which have complete data required by the researcher.

This research used secondary data taken from annual financial statements and Indonesian Capital Market Directory (ICMD) from manufacturing companies listed on the Indonesia Stock Exchange from 2012 to 2016. Multiple linear regression using Eviews 8 was used to analyze the data. The dependent variable in research was capital structure. The capital structure in this study was measured by the ratio of debt to equity ratio (DER). According to Kasmir (2012) debt to equity ratio is used to assess debt with equity. The function of this ratio is to find out each rupiah own capital used for debt guarantees. The formula for finding debt to equity ratio can be used as a comparison between the total debts with total equity. The independent variables consist of managerial ownership, institutional ownership, profitability, company size and tangibility.

Yeniatie and Destriana (2010) said that managerial ownership is the amount of management ownership that actively incorporate with corporate decision-makers (directors and commissioners). Managerial ownership is proxied by the percentage of share ownership by managers, directors and commissioners of the company compared to the number of shares outstanding. According to Laksana and Widyawati (2016), institutional ownership is shares ownership by governments, financial institutions, legal institutions, foreign institutions, trust funds and other institutions. Institutional ownership is the proportion of shares held by the institution at the end of the year which is measured by percentage. Variables of institutional ownership can be formulated by comparing the number of shares owned by the institution with the number of shares outstanding (Nabela, 2012).

Profitability is the level of net profit which can be generated by the company in its operations (Ridloah, 2010). According to Laksana and Widyawati (2016) profitability is one the measurement for a company's performance. According to Kasmir (2012), profitability is measured by return on assets. This ratio is used to measure the effectiveness of the overall company's operations. According to Zuhria and Riharjo (2016) firm size is the size or amount of assets owned by the com- 
pany. According to Budiasih (2009) company size is measured by the total assets which are proxied with total assets of the company (Total Assets).

According to Widianti and Andayani (2015), the asset structure (tangibility) is the balance or ratio between fixed assets and total assets, consist of fixed assets, intangible assets, current assets and non-current assets.

This research used multiple linear regression model to test the hypothesis. The regression model is as follow:

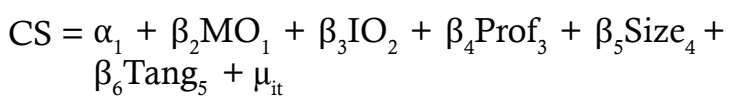

$\begin{array}{ll}\text { CS } & \text { : Capital Structure } \\ \text { MO } & \text { : Manajerial Ownership } \\ \text { IO } & \text { : Institutional Ownership } \\ \text { Prof } & \text { : Profitability } \\ \text { Size } & \text { : Firm Size } \\ \text { Tang } & \text { : Tangibility }\end{array}$

\section{RESULTS AND DISCUSSION}

Statistical descriptive from Table 2 shows that the highest value of DER is owned by PT Tembaga Mulia Semanan Tbk, is 10.12000 while the lowest value is owned by PT Jaya Pari Steel Tbk is 0.040000 with mean is 1.417332 and the standard deviation is 1.720228 . Standard deviation is 1.720228 means that deviation from the data variation is 1.720228 from the mean value. Mean 1.417332 means that the average corporate debt is 1.417332 times the total equity of the company.

From Table 2 it can be seen that the highest value of managerial ownership in PT Wismilak Inti Makmur Tbk company, that is 0.475200 while the lowest value is owned by PT Gunawan Dianjaya Steel Tbk is 0.000100 , with a mean value is 0.070293 and the standard deviation is 0.097087 . Standard deviation is 0.097087 means that the deviation to the data variation is 0.097087 from the average. Mean is 0.070293 means that the average proportion of shares owned managerial is 0.070293 times the number of shares outstanding.

The highest value of institutional ownership is owned by PT Gunawan Dianjaya Steel Tbk, is 0.979900 while the lowest value is owned by PT Wismilak Inti Makmur Tbk, is 0.224800 . Mean is 0.690779 and the standard deviation is 0.167154 . Standard deviation is 0.167154 means deviation to the data variation is 0.167154 from the mean value. The mean value is 0.690779 means that the average proportion of shares owned by the institutional is 0.690779 times the number of shares outstanding.

The highest value of Profitability is 19.69000 owned by PT Lion Metal Works Tbk, while the lowest value is owned by PT Jakarta Kyoei Steel Tbk is -5.900000 . Mean is 4.161895 and the standard deviation is 5.099252. Standard deviation is 5.099252 means deviation to the data variation is 5.099252 from the mean value. The mean value is 4.161895 means that the average net profit after tax is 4.161895 times the total amount of assets.

The highest value of firm size is owned by PT Indofood Sukses Makmur Tbk is 18.33550 while the lowest value is owned by PT Kedaung Indah Can Tbk is 11.46120. The mean value is 14.04127 and the standard deviation is 1.549543 . Standard deviation is 1.549543 means that the deviation to the data variation is 1.549543 from the average value. The mean value greater than the standard deviation value means that almost all manufacturing companies have the same company size, the data deviation is evenly distributed and the spread of data is evenly distributed.

From Table 2 it can be seen that the highest value is owned by PT Indo Kordsa Tbk is 1.071300 , while the lowest value is owned by PT Jaya Pari Steel Tbk is $0,032,000$. The mean value is 0.3719943 and the standard deviation is 0.211339 . Standard deviation is 0.211339 means the deviation to the data variation is 0.211339 from the mean value. The mean value is 0.3719943 means that the average fixed asset is 0.3719943 times the total amount of the asset.

Table 2. Descriptive Statistics

\begin{tabular}{crrrrr}
\hline Variabel & \multicolumn{1}{c}{ Mean } & \multicolumn{1}{c}{ Median } & Maximum & Minimum & Std. Dev. \\
\hline DER & 1.417332 & .915000 & 10.120000 & .040000 & 1.720228 \\
MOWN & .070293 & .019000 & .475200 & .000100 & .097087 \\
INST & .690779 & .712600 & .979900 & .224800 & .167154 \\
ROA & 4.161895 & 3.380000 & 19.690000 & -5.900000 & 5.099252 \\
SIZE & 14.041270 & 13.97960 & 18.335500 & 11.461200 & 1.549543 \\
SA & .371943 & .358050 & 1.071300 & .032000 & .211339 \\
\hline
\end{tabular}


Table 3. The Results of Statistical-F Test

\begin{tabular}{cccc}
\hline R-squared & Adjusted R-squared & F-statistic & Prob(F-statistic) \\
\hline .908193 & .881963 & 3.462 .355 & .000000 \\
\hline
\end{tabular}

Table 4. Results of Statistical t-Test

\begin{tabular}{ccccc}
\hline Variable & Coefficient & Std. Error & t-Statistic & Prob. \\
\hline C & 3.485165 & 2.052007 & -1.698418 & .0915 \\
MOWN & 5.456417 & 2.451308 & 2.225921 & .0275 \\
INST & -1.946158 & 1.101343 & -1.767077 & .0793 \\
ROA & -.008707 & .008336 & -1.044457 & .2980 \\
SIZE & .285092 & .131195 & 2.173035 & .0314 \\
SA & .788547 & .347962 & 2.266187 & .0249 \\
\hline
\end{tabular}

Based on Table 4 shows the results of multiple regression analysis, obtained by regression equation as follows: $\operatorname{DER}(\mathrm{Y})=$ $3.485165+5.456417 \mathrm{MWON}-1.946158 \mathrm{INST}$ $0.008707 \mathrm{ROA}+0.285092 \mathrm{SIZE}+0.788547 \mathrm{SA}$ + e. In Table 3 Adjusted R-Square results is 0.908193 . It means that $90.81 \%$ of capital structure variation can be explained by variations of independent variables: managerial ownership, institutional ownership, profitability, company size and tangibility, while the remaining is $9.19 \%$ explained by other variables outside the model. The value of $\mathrm{F}$ arithmetic is 34.62355 with probability (Prob F-statistic) is 0.000000.

Since the probability is less than 0.05 , it indicates that independent variables that are managerial ownership, institutional ownership, profitability, company size and tangibility simultaneously affect dependent variable that is a capital structure at manufacturing companies in BEI period 2012-2016.

Managerial ownership has a positive regression coefficient is 5.456417 with a probability value of significance is $0.0275<0.05$, it can be concluded that managerial ownership has a significant positive effect on capital structure. Institutional ownership has a coefficient is -1.946158 with a probability value of significance is 0.0793 $>0.05$. This shows that institutional ownership has no significant negative effect on capital structure.

The coefficient of profitability is -0.008707 with a probability value is $0.2980>0.05$. This shows that profitability does not have a significant negative effect on capital structure. The coefficient of firm size is 0.285092 with a probability value of significance is $0.0314<0.05$. This shows that company size has a significant positive effect on capital structure.
Tangibility or asset structure has a coefficient is 0.788547 with a probability value of significance is $0.0249<0.05$. This shows that tangibility has a significant positive effect on capital structure.

\section{The Effect Of Managerial Ownership On Capital Structure}

The result of hypothesis test shows that managerial ownership variable which is proxied by MOWN has regression coefficient value is 5.456417 using $\mathrm{n}$ significance level 5\% obtained significance value is $0.0275<0.05$, meaning H0 is accepted and Halis rejected. Ha1 which states that "Managerial ownership has a significant negative effect on capital structure" is rejected.

Based on the research result, managerial ownership has a significant positive effect against the capital structure which is proxied by DER at manufacturing company listed on the Indonesia Stock Exchange period 2012-2016. The increased of managers shareholding will affect the increasing use of debt.

This is because the increase of shares ownership by managers will encourage managers to have entrenchment behavior. Therefore shareholders will increase the debt as a creditor monitoring mechanism against managerial performance. The increase in managerial ownership will encourage management to utilize corporate funds for the sake of managers' interest, so it is necessary to do effective monitoring by increasing debt to reduce agency problems.

The results of this study are in line with research by Shoaib and Yasushi (2015) and Yulianto (2013) said that managerial ownership has a significant positive effect on capital structure. But the results of this study are not in line with the research by Hasan and Butt (2009) and Sumani 
(2012) which shows the relationship of the significant negative effect of managerial ownership on capital structure.

\section{The Effect of Institutional Ownership on Capital Structure}

The result of hypothesis testing showed that the institutional ownership variable which is proxied by INST has regression coefficient value is -1.946158 by using $\mathrm{n}$ significance level $5 \%$ obtained significance value is $0.0793>0.05$, meaning $\mathrm{H} 0$ is accepted and $\mathrm{Ha} 1$ is rejected. $\mathrm{Ha} 1$ which states that "Institutional ownership has a significant negative effect on capital structure" is rejected.

Based on the research result, institutional ownership has an insignificant negative effect on the capital structure at manufacturing company listed on the Indonesia Stock Exchange (BEI) in the period 2012-2016. This institutional ownership behavior is not in line with the predictions according to theoretical. This institutional ownership variable does not show any influence on capital structure.

According et al. (2012) high institutional ownership does not guarantee that the company has strict control over the manager so that the act of seeking funding company by external parties in the form of debt will be more suppressed and controlled. Although the company has big sufficient of institutional ownership, it is not able to become a controller on the use of corporate debt.

Institutional ownership concentrates on investment in the company and it is not involved in the decision-making process by the managers if the institution does not feel satisfied yet with the performance of their management that sell its shares to the capital market, so the company less concerned with institutional ownership in decision-making.

The results of this study are in line with research by Susilawati et al. (2012) says that institutional ownership has an insignificant negative effect on capital structure. However, the results of this study are not in line with research by Chung and Wang (2014) and Rossi and Cebula (2016) say that there is a significant negative effect of institutional ownership on the capital structure and Laksana and Widyawati (2016) and Maftukhah (2013) institutional ownership has a significant positive effect on capital structure.

\section{The Effect of Profitability on Capital Structure}

Pecking order theory shows that a company with high profits will lower the cost of debt because there are more internal funds for financial investment. Internal funding is used first by the company because it is considered to have a low cost. The second is external funding that is debt and the last is issuing shares (Myers \& Majluf, 1984).

The result of hypothesis testing shows that profitability variable which is proxied by ROA has regression coefficient value is -0.008707 with n significance level $5 \%$ obtained significance value is $0.2980>0.05$, meaning H0 is accepted and $\mathrm{Ha} 1$ is rejected. Ha1 which states that "Profitability has a significant negative effect on capital structure" is rejected.

Based on the research result, profitability has an insignificant negative effect on the capital structure at manufacturing companies listed on the Indonesia Stock Exchange (BEI) in the period 2012-2016. This study does not support the hypothesis of the research. The Company has established its capital structure based on the number of returns and sacrifices (capital costs) which is obtained from the use of debt to support the company's operations. Company with high profitability prefer to use debt to fulfill the company's funds because of the benefits of debt caused by interest costs will be deductible with corporate tax (Brigham \& Houston, 2013).

The results of this study are in line with research by Nisak and Ardiansari (2016) said that profitability has negative and insignificant effect on capital structure. But the results of this study are not in line with research conducted by Indriani and Widyarti (2013) which says that profitability has a significant negative effect on the capital structure and Nugroho (2014) says that there is a significant positive effect of profitability against the capital structure.

\section{The Effect of Firm Size on Capital Structure}

The result of hypothesis testing shows that firm size variable which is proxied by SIZE have regression coefficient value is 0.285092 using $n$ significance level $5 \%$ obtained significance value is $0.0314<0.05$, meaning $\mathrm{H} 0$ is rejected and $\mathrm{Ha} 1$ is accepted. Ha1 which states that "The size of the company has a significant positive effect on capital structure" is accepted.

Based on the research, firm size has a positive and significant effect on the capital structure at manufacturing companies listed on the Indonesia Stock Exchange (IDX) in the period 20122016. The positive effect of company size indicates that the larger the firm size, the greater the company's ability to do external funding. And conversely, the smaller the company, the lower the opportunity to get external funding. 
The larger the firm size, the greater the need for funds, which one of them can come from external funding, that is debt. Large companies have special quality and activity which is known by the public rather than small companies, so the huge need for corporate debt will be higher than that of small companies.

In addition, the larger the company, the more transparent in expressing the company's performance against outsiders, so the company will be easier to get a loan because it is more trusted by the creditors of the company (Sudiyatno \& Sari, 2013). This is in line with pecking order theory which says that companies prefer to use internal funding, but if it is not enough, the second alternative is to use debt and then the last is to issue shares.

The results of this study are in accordance with research by Zuhria and Riharjo (2016) and Oino and Ukaegbu (2015) which say that firm size has a significant positive effect on capital structure. But the results of this study are not in accordance with the research by Nugroho (2014) says that there is a significant negative effect of company size on capital structure.

\section{The Effect of Asset Structure (Tangibility) on Capital Structure}

The result of hypothesis testing shows that tangibility variable which is proxied by SA has regression coefficient value is 0.788547 using $n$ significance level $5 \%$ obtained significance value is $0.0249<0.05$, meaning $\mathrm{H} 0$ is rejected and $\mathrm{Ha} 1$ is accepted. Ha1 which states that "Tangibility has a significant positive effect on capital structu$\mathrm{re}$ " is accepted.

Based on the research result, tangibility has a significant positive effect on the capital structure at manufacturing companies listed on the Indonesia Stock Exchange (IDX) in the period 2012-2016. The positive effect of tangibility means that the greater the tangibility of the company, the greater the capital structure or, the greater the company in using external funds that is debt.

Large assets will show the company's ability to provide higher assurance, so by assuming all other factors are constant; the company will increase its debt to get profits from the used of debt (Agustini \& Budiyanto, 2015). According to Laksana and Widyawati (2016) with high levels of tangibility, if the company is experiencing financial difficulties or even bankruptcy, the creditor is entitled to the guaranteed tangible assets of the company. Companies with a large proportion of their assets composed of tangible assets will tend to have high debt levels. Conversely, the lo- wer the tangibility of the company, the lower the ability of the company to be able to guarantee its long-term debt.

The results of this study are in line with the research by Hardiningsih and Oktaviani (2012) and Agustini and Budiyanto (2015) say that tangibility has a significant positive effect on capital structure. But the results of this study are not in line with the research by Yuhasril (2006) says that there is a significant negative effect of tangibility (assets structure) on capital structure.

\section{CONCLUSION AND RECOMMENDATION}

Based on the research result which has been done by using 38 samples at manufacturing companies listed on the Indonesia Stock Exchange (BEI) in the period 2012-2016, so the conclusions are:

Managerial ownership has a positive and significant effect on capital structure. Institutional ownership has a negative and insignificant effect on capital structure. Profitability has negative and insignificant effect on capital structure. Company size has a significant positive effect on capital structure. The asset structure (tangibility) has a significant positive effect on capital structure.

Suggestions given in this research, the company, should pay more attention to managerial ownership, company size and assets structure of the company in making a decision of capital structure. For investors should pay attention to managerial ownership, company size and asset structure (tangibility) in making investments, while for further researchers should increase the number of samples besides manufacturing companies and use a longer period.

\section{REFERENCES}

Agustini, T., \& Budiyanto, B. (2015). Pengaruh Struktur Aktiva, Profitabilitas dan Ukuran Perusahaan terhadap Struktur Modal. Jurnal Ilmu dan Riset Akuntansi, 4(8), 1-18.

Anita, A., \& Yulianto, A. (2016). Pengaruh Kepemilikan Manajerial dan Kebijakan Dividen terhadap Nilai Perusahaan. Management Analysis Journal, 5(1), 17-23.

Brigham, E. F., \& Houston, J. F. 2013. Dasar-Dasar Manajemen Keuangan 11th ed. Jakarta: Salemba Empat.

Budiasih, I. (2009). Faktor-Faktor yang Mempengaruhi Praktik Perataan Laba. Jurnal Ilmiah Akuntansi dan Bisnis, 4(1), 1-14.

Chung, C. Y., \& Wang, K. (2014). Do Institutional Investors Monitor Management? Evidence trom the Relationship between Institutional Ownership and Capital Structure. The North American 
Journal of Economics and Finance, 30, 203-233.

Febriana, D., \& Yulianto, A. (2012). Pengujian Pecking Order Theory di Indonesia. Management Analysis Journal, 1(2), 120-128.

Hardiningsih, P., \& Oktaviani, R. M. (2012). Determinan Kebijakan Hutang (dalam Agency Theory dan Pecking Order Theory). Dinamika Akuntansi Keuangan dan Perbankan, 1(1), 11-24.

Haryanto, S. (2013). Identifikasi Ekspektasi Investor melalui Kebijakan Struktur Modal, Profitabilitas, Ukuran Perusahaan dan GCPI. Jurnal Dinamika Manajemen, 4(2), 184-191.

Hasan, A., \& Butt, S. A., (2009). Impact of Ownership Structure and Corporate Governance on Capital Structure of Pakistan Listed Companies. International Journal of Business and Management, 4(2), 50-57.

Indriani, A., \& Widyarti, E. T. (2013). Penentu-Penentu Struktur Modal Perusahaan yang Sahamnya Masuk Jakarta Islamic Index. Jurnal Dinamika Manajemen, 4(1), 184-91.

Jensen, M. C., \& Meckling, W. H. (1976). Theory of the Firm: Managerial Behavior, Agency Costs and Ownership Structure. Journal of Financial Economics, 3(4), 305-360.

Kasmir. (2012). Analisis Laporan Keuangan. Jakarta: PT. Raja Grafindo Persada.

Khafid, M., \& Nurlaili, D. (2017). The Mediating Role of Accountability in the Influence of Cooperative Characteristics on its Financial Performance. International Journal of Economic Research, 14(5), 191-200.

Komara, A., Hartoyo, S., \& Andati, T. (2016). Analisis Pengaruh Struktur Modal terhadap Kinerja Keuangan Perusahaan. Jurnal Keuangan dan Perbankan, 20(1), 10-21.

Laksana, I. F., \& Widyawati, D. (2016). Pengaruh Kepemilikan Saham, Kebijakan Dividen, Tangibility, Size dan Profitabilitas terhadap Struktur Modal. Jurnal Ilmu dan Riset Akuntansi, 5(4), $1-18$.

Maftukhah, I. (2013). Kepemilikan Manajerial, Kepemilikan Institusional dan Kinerja Keuangan sebagai Penentu Struktur Modal Perusahaan. Jurnal Dinamika Manajemen, 4(1), 69-81.

Matias, F., \& Serrasqueiro, Z. (2016). Are There Reliable Determinant Factors of Capital Structure Decisions? Empirical Study of Smes in Different Regions of Portugal. Research in International Business and Finance, 40, 19-33.

Moh'd, M. A., Perry, L. G., \& Rimbey, J. N. (1998). The Impact of Ownership Structure on Corporate Debt Policy: a Time-Series Cross-Sectional Analysis. Financial Review, 33(3), 85-98.

Myers, S. C., \& Majluf, N. S. (1984). Corporate Financing and Investment Decisions When Firms Have Information that Investors do Not Have. Journal of Financial Economics, 13(2), 187-221.

Nabela, Y. (2012). Pengaruh Kepemilikan Institusional, Kebijakan Dividen dan Profitabilitas terhadap Kebijakan Hutang pada Perusahaan Properti dan Real Estate di Bursa Efek Indonesia.
Jurnal Manajemen, 1(1), 1-8.

Natasia, W., \& Wahidahwati, W. (2011). Faktor-Faktor yang Mempengaruhi Kebijakan Hutang Perusahaan yang Terdaftar di BEI. Jurnal Bisnis dan Akuntansi, 13(3), 163-181.

Nisak, N. K., \& Ardiansari, A. (2016). Analisis FaktorFaktor yang Mempengaruhi Struktur Modal serta Pengaruhnya terhadap Harga Saham pada Perusahaan-Perusahaan yang Tergabung dalam LQ45 Periode Tahun 2011-2013. Management Analysis Journal, 5(2), 88-95.

Nugroho, N. C. (2014). Analisis Pengaruh Profitabilitas, Pertumbuhan Penjualan, Ukuran Perusahaan dan Umur Perusahaan terhadap Struktur Modal Usaha Mikro Kecil dan Menengah Kerajinan Kuningan di Kabupaten Pati. Management Analysis Journal, 3(2), 6-10.

Oino, I., \& Ukaegbu, B. (2015). The Impact of Profitability on Capital Structure and Speed of Adjustment: an Empirical Examination of Selected Firms in Nigerian Stock Exchange. Research in International Business and Finance, 35, 111-121.

Pratiwi, R., \& Yulianto, A. (2016). Pengaruh Struktur Kepemilikan dan Komisaris Independen terhadap Biaya Keagenan Perusahaan yang Masuk dalam Indonesia Most Trusted Companies. Management Analysis Journal, 5(3), 215-228.

Pujiharjanto, C. A., Nilmawati, N., \& Gusaptono, R. H. (2014). Identifikasi Variabel Penentu Struktur Modal dan Adjustment to Target Capital Structure: Trade-off Theory. Jurnal Keuangan dan Perbankan, 18(3), 358-369.

Ridloah, S. (2010). Faktor Penentu Struktur Modal: Studi Empirik pada Perusahaan Multifinansial. Jurnal Dinamika Manajemen, 1(2), 144-153.

Rossi, F., \& Cebula, R. J. (2016). Debt and Ownership Structure: Evidence from Italy. Corporate Governance: the International Journal of Business in Society, 16(5), 883-905.

Salehi, M., Lotfi, A., \& Farhangdoust, S. (2017). The Effect of Financial Distress Costs on Ownership Structure and Debt Policy: an Application of Simultaneous Equations in Iran. Journal of Management Development, 36(10), 1216-1229.

Sheisarvian, R. M., Sudjana, N., \& Saifi, M. (2015). Pengaruh Kepemilikan Manajerial, Kebijakan Dividen dan Profitabilitas terhadap Kebijakan Hutang (Studi pada Perusahaan Manufaktur yang Tercatat di BEI Periode 2010-2012). Jurnal Administrasi Bisnis, 22(1), 1-9.

Shoaib, K., \& Yasushi, S. (2015). Capital Structure and Managerial Ownership: Evidence from Pakistan. Business and Economic Horizons, 11(2), 131-142.

Sudiyatno, B., \& Sari, S. M. (2013). Determinants of Debt Policy: an Empirical Studying Indonesia Stock Exchange. Journal of Educational Research, 4(1), 98-108.

Sumani. (2012). Determinan Struktur Modal dan Nilai Perusahaan Pertambangan Pasca UU Nomor 4 Tahun 2009. Jurnal Ekonomi dan Keuangan, 80, 24-41. 
Tika Iswarini \& Anindya Ardiansari/ Management Analysis Journal 7(4) (2018)

Susilawati, C. D. K., Agustina, L., \& Tin, S. (2012). Faktor-Faktor yang Mempengaruhi Kebijakan Hutang (Perusahaan Manufaktur yang Terdaftar di Bursa Efek Indonesia). Jurnal Keuangan dan Perbankan, 16(2), 178-187.

Widianti, E. A., \& Andayani. (2015). Pengaruh Profitabilitas, Ukuran Perusahaan dan Struktur Aktiva terhadap Struktur Modal. Jurnal Ilmu dan Riset Akuntansi, 4(10), 1-15.

Yeniatie, Y., \& Destriana, N. (2010). Faktor-Faktor yang Mempengaruhi Kebijakan Hutang pada Perusahaan Nonkeuangan yang Terdaftar di Bursa Efek Indonesia. Jurnal Bisnis dan Akuntansi, 12(1), 1-16.

Yuhasril. (2006). Analisis Faktor-Faktor yang Mempengaruhi Struktur Modal Perusahaan Farma- si yang Telah Go Publik di Bursa Efek Jakarta. BULETIN Penelitian, (9), 1-11.

Yulianto, A. (2013). Keputusan Struktur Modal dan Kebijakan Dividen sebagai Mekanisme Mengurangi Masalah Keagenan. Jurnal Dinamika Manajemen, 4(2), 164-183.

Yulianto, A., Suseno, D. A., \& Widiyanto, W. (2015). Testing Pecking Order Theory and Trade Off Theory Models in Public Companies in Indonesia. Handbook on Business Strategy and Social Sciences, 3, 13-18.

Zuhria, S. F., \& Riharjo, I. B. (2016). Pengaruh Profitabilitas, Free Cash Flow, Pertumbuhan Penjualan, Ukuran Perusahaan terhadap Kebijakan Hutang. Jurnal Ilmu dan Riset Akuntansi, 5(11). $1-21$. 